\title{
The Legend of St. Sisynnios in Ethiopian Charms: Interconnection with His Life
}

\author{
Ekaterina V. Gusarova \\ Research Fellow, Institute of Oriental Manuscripts of Russian Academy of Sciences
}

\begin{abstract}
The legend of St. Sisynnios has been widespread in both Christian and popular Ethiopian tradition up to the present time. It exists in the form of written texts in the Ge'ez language, inserted in so-called magic scrolls among other closely connected texts of both magical and religious character. These scrolls have a protective function, and St. Sisynnios is venerated by the Ethiopian Church. There are two versions of his life. The shorter one comprises part of the Synaxarion whilethe longer one is included in a corpus of hagiographical compilations entitled "The Lives of the Martyrs". Both of these were translated from the Arabic prototype, borrowed from the mother Coptic Church of Alexandria. There is a notable interconnection between the legend in the amulets and the religious texts. It is unknown whether the text of the legend once existed in form of verbal charm or not. In any case, different elements of the saint's life passed to the legend. Some have remained unchanged while others have undergone transformations or lost some elements. It is important to study different elements of the legend using the examples conserved in the available manuscript scrolls. Analysis of these interconnections and the evolution of the text constitutes the basis of the present research.
\end{abstract}

Keywords: St. Sisynnios, legends, Ethiopian Synaxarion, Coptic Synaxarion, witches, manuscripts, magic scrolls, traditional medicine

The legend of St. Sisynnios is a common plot present in different cultures all over the world ${ }^{1}$ and is also an integral part of Ethiopian apocryphal literature. The story of his life was adopted as a part of the corpus of religious literature borrowed from the mother Coptic Church. ${ }^{2}$ The translation of religious literature to Ge'ez began after the $4^{\text {th }}$ century, with the arrival of the Christian faith in the Horn of Africa and the acceptance of Christianity as an official religion in Axum. As far is the text of St. Sisynnios' Vita is

\footnotetext{
1 A detailed overview of the legend in different traditions has recently been realized by a group of authors (see L'AVIANSKII et al. 2017).

2 This fact is confirmed by the absolute identity of the Arabic and Ethiopic texts of the Vitae of the Saint.
} 
concerned, it is highly likely to have been translated in the $14^{\text {th }}-15^{\text {th }}$ centuries, as taken from the Arabic version, when the language took the place of Coptic in the Church of Alexandria. Soon thereafter, the text entered local tradition, both literal and oral.

The Vita narrates the battle between the saint and the evil female force called Wurzelya. The legend has survived up to our days due to its transmission in written form. Its material support is represented by protective amulets, mostly in form of scrolls, which were usually worn on a textile lace around the neck or mounted on a wall in dwellings.

The wearing of such kind of amulets is one of the magical practices generally widespread among Ethiopian Christians. The scrolls were used by the majority of Ethiopians in spite of the fact that magic was obviously prohibited by the Church and a severe punishment was decreed for fabrication of the scrolls and filling them with the texts. In Ethiopia, the magic itself had numerous Christian characteristics. It implied the obligatory presence of texts written in the old Ethiopic language Ge'ez and in artistic decoration, which mostly comprised subject matter of Christian origin. Extracts from Holy Scriptures were alternated by texts of purely magical character (comprising the names of demons, magical letters non-existent in the alphabet etc.). As the language was no longer in use (at least from the beginning from the $13^{\text {th }}$ century), it was incomprehensible for the absolute majority of the people. Hence, the scrolls were not destined to be read; instead, the physical presence of the written text was their main semantic load. It was believed that all illnesses and accidents were caused by ghosts and demons and that the amulets protected people from such evil forces. The moment when the relative oral tradition (legend) was created and when it was transformed in written form to continue its existence on the parchment scrolls exclusively is unknown. ${ }^{3}$ Nowadays, the legend is no longer prevalent among the people and it is not part of modern folklore.

The scrolls were used by both men and women. The female amulets had to protect women from problems connected to the pregnancy, childbirth and bleeding in the womb. The St. Sisynnios legend was normally included in such scrolls as it describes the victory of the saint over the witch who used to kill new-born children by sucking out their blood and to provoke bleeding in the womb's of their mothers.

The legend includes the first part of the official vita of the saint, modified in a certain way. ${ }^{4}$ In both the vita and the legend, the saint fights with the female killer of the children (the sister of the saint in the vita, and a witch in the legend).

The plot of the vita is as follows. A man called Sisynnios lived in Antiochia in the times of the Emperor Diocletian. He leaved his native city and upon returning later realized that his sister gave birth to a girl, killed the baby and sucked its blood.

3 Parchment scrolls, worn or mounted in houses (sometimes with extensive humidity) were easily damaged and corrupted. Sometimes they were put in the tomb of a deceased person (for reasons of protection - a common tradition for the north-eastern African peoples such as the Egyptians and Nubians). Few parchment scrolls anterior to the $17^{\text {th }}$ century have survived.

4 The text of the vita arrived in Ethiopia from Coptic tradition and was then translated from the Arabic language into Ge'ez. The short versions of the Synnaxar texts are equal. See edition of the text in: COLIN 1995. For Arabic version see: BASSET 1922. The extensive version, included in the collection of hagiographyc texts known as Gedla Same'etat (Vitae of the martyrs) (BAUsi 2005). The main difference is that the long version includes a detailed descriptionof all the tortures of the saint. 
After that she gave birth to a boy of an unhuman appearance. Moreover, she then began killing new-born children all over the country. The saint kills the witch and her child (as he is a son of the Devil) and her husband (as he is possessed by the evil forces).

In the longer version, the father of Sisynnios is from a close circle of the emperor. Sisynnios is sent to Nicomidia, where he becomes Christian. Coming back to Antiochia, he realizes that his sister gave birth to a girl, killed the baby and sucked its blood. Moreover, she was able to take the form of a bird or a snake. She then gives birth to a boy of an unhuman appearance. The saint kills the witch, her child and her husband. When the father of Sisynnios finds out about his son's deed (the fact that he killed his sister, the child killer, her child and husband), he brings him to Diocletian for punishment. Diocletian is a pagan and he tries to make Sisynnios offer sacrifices to the gods in sanctuaries, but the gods break in the presence of Sisynnios. Then Sisynnios is tormented, tortured and finally killed. His soul is immediately taken by the angels and ascends to the Heavens.

Presumably, once the vita once entered popular tradition, it was then modified and in course of time lost some parts of the narration while others were elaborated. In approaching the texts conserved in the manuscript scrolls, it must be faced the problem of various lacuna in the text and damaged sections which make understanding of the general line of the narrative difficult. A comparison of a number of copies makes it possible to reconstitute the following sequence of events. A man called Sisynnios (St. Sisynnios) gets married and one or two children are born to his wife, but a witch called Wurzelya comes to the wife of the man and kills the baby. The wife is crying. Sisynnios hears her lamentation and asks her about the reason for her crying. She relates what has happened and the saint begins searcing for the witch. On his way, he meets an old lady, asking her about the location of Wurzelya. She replies that the witch is in the forest (garden) in front of him. The saint enters the forest and finds Wurzelya under a tree surrounded by an army of evil forces (ghosts). The saint dismounts from his horse, gets on his knees and addresses a prayer to the Savior, asking him for help in killing the witch to prevent her killing babies. A voice from the Heaven gives him permission to do everything he desires with Wurzelya. Therefore, the Saint mounts his horse, takes his sword in his right hand and pierces her side.

The end of the story differs greatly from one manuscript to another. These include the following variants. First: Wurzelya is killed. Second: Wurzelya is killed and swears by the names of the Archangels not to come close to houses where children are born, nor to approach their mothers or any location where the prayer (legend) of St. Sisynnios is read (written down). Third: Wurzelya's side is pierced, but she does not die, swearing not to kill new-born children and not to come close (see the second variant above). Wurzelya promises to go to the church and to become a good Christian. Consequently (and constantly), the saint becomes the protector of the new-born children and women in childbirth. These three variants of the plot, with slight differences, are common to the absolute majority of the manuscript scrolls containing the legend. Only one attested scroll stands apart. ${ }^{5}$ Here, the beginning of the story presents new, lively details concerning the scene of the mother's meeting with the witch, highlighted by dialogues and actions.

\footnotetext{
5 Manuscript parchment scroll, Eth. 119 from the Institute of Oriental Manuscripts of the Russian Academy of Sciences (St. Petersburg, Russia). $17^{\text {th }}-18^{\text {th }}$ century; contains magical prayers and the legend of St. Sisynnios.
} 
The existence of different versions of the narrative confirms that the legend passed through a long process of evolution in popular use and as a product of the kalam of copyists within the rich literal tradition maintained by Ethiopian scribes. Having analysed dozens of texts and research studies dedicated to the legend, the initial core of St. Sisynnios legend is still not very clear. It could have been short in the beginning and then enhanced with additional details over the centuries of its existence or, on the contrary, derived in a longer version from the vitae of the saint. In this case, the plot could have transformed in the process of oral transmission. On the other hand, the folklore version could have been derived not from oral transmission, but instead in the process of multiple copy-making, with the relative additions and corrections (and mistakes or omissions) of the scribes.

St. Sisynnios is one of the equestrian Saints widely respected in Ethiopia. ${ }^{6}$ Even so, his images are not as popular as those of the Archangel Michael or St. George the Victorious. Consequently, it is not much what can be said about his iconography. Images of the saint are rarely included in the scrolls or depicted on the altars of churches. On the basis of the few available examples, it can be concluded that the main principle of the iconography is identical to that of St. George. The horse is white and he carries a spear in his right hand. Only the evil force under the hooves is different. St. George kills the serpent (dragon) and St. Sisynnios kills the female witch. Visual representations, though rare, are always solemn and bright. ${ }^{7}$ They illustrate the victory of good over evil, the central motif of the Christian faith. The evil forces are defeated, often by the sword. ${ }^{8}$

It is worth mentioning that Ethiopians are generally prone to superstition and magical practices. In the countryside - but not exclusively there (!) - people often fear evil forces, consult fortune tellers and so-called sorcerers and order the fabrication of protective scrolls. The scrolls, fabricated for tourists as souvenirs, sometimes represent archaic features in both contents (copied from a much older prototype) and the manner of writing. Today they are rarely worn on necklaces, but are mounted instead in a house. ${ }^{9}$ Since the scrolls are often made for tourists, the St. Sisynnios' legend continues to be used in written form in Ethiopia.

\section{REFERENCES CITED}

BALICKA-WiTAKOWSKA, Ewa

2005 Equestrian Saints. In Uhlig, Siegbert (ed.) Encyclopaedia Aethiopica 2. 347-351. Wiesbaden: Harrassowitz.

6 See for instance: BaLICKA-WitAKOWSKA 2005.

7 Ethiopian fine art is quite schematic, symbolic in character and idiosyncratic. It stands apart both from the general Christian tradition (though developed under the Byzantine influence) and from local African art. To perceive it in a proper manner, one requires a special approach and preparation.

8 Frequently, one sword is depicted stuck in the body of Wurzelya and another in the right hand of the Saint. This illustrates the wish of the Ethiopians not to leave the saint alone, unprotected, with no weapon, always ready to fight evil (an ingenious way!). Another similar example - the icons of St. Takla Haymanot. According to his vitae, he lost one leg at the end of his life. Out of compassion for this saint, Ethiopian painters depict his leg nearby, him standing on one leg.

9 This proves that the living practice has become a habitual tradition. 
BASSET, René (Arabic text published, translated and annotated)

1922 Le Synaxaire arabe jacobite (rédaction copte). IV Les mois de barmahat, barmoudah et bachons [The Arab Jacobite Synnaxar (Coptic redaction). IV The Months of Barmahat, Barmoudah and Bachons]. Patrologia Orientalis 16:185-424 (827-1066). Paris: Firmin-Didotetcie.

BAUSI, Alessandro

2005 Gädlä Säma'ətat [Vitae of the Martyrs]. In UhLıG, Siegbert (ed.) Encyclopaedia Aethiopica 2. 644-646. Wiesbaden: Harrassowitz.

Colin, Gérard (Critical edition of the Ethiopian text and French translations)

1995 Le Synaxaire Éthiopien. Mois de Miyāzyā [The Ethiopian Synaxar. Miyāzyā Month]. Patrologia Orientalis 46/4(208):481-600 (1-120). Turnhout: Brepols.

L'avdanskiI, Aleksei K. - Smagina, Yevgeniia B. - Agapkina, Tatiana A. - RychKov, Aleksandr L. (eds.)

2017 Sisinieva legenda $v$ fol'klornykh $i$ rukopisnykh traditsiiakh Blizhnego Vostoka, Balkan I Vostochnoi Evropy [The Sisynnios Legend in Folklore and Manuscripts Traditions of the Middle East, Balkans and Europe]. Moskva: Indrik.

Ekaterina Valentinovna Gusarova (1983) studied at the Faculty of Oriental Studies (African Studies Department) of St. Petersburg State University, and at the Facoltà di Studi Arabo-Islamici (Istituto "L' Orientale") of the Università degli Studi di Napoli. She earned her PhD in General History (Middle Ages) at the Institute of Oriental Manuscripts of the Russian Academy of Sciences (RAS), being her field of specialization the History of Ethiopia). Since 2012 she has been a librarian in the Manuscript Department of the National Library of Russia, and, since 2013, a fellow researcher at the Institute of Oriental Manuscripts of the RAS. Since 2016 she has been teaching Arabic at the Higher School of Economics of the National Research University (St. Petersburg). Being her main research areas Ethiopian studies, Islamic studies, History of the Middle East and of the Oriental Churches, and Oriental Christian art, she has authored over 50 articles and book chapters on these subjects. E-mail: ekater-ina@mail.ru 